\title{
STATEN OG DE MATERIELLE PRODUKTIONSBETINGELSER
}

\section{Tyge Kjær}

\section{Indledning}

I diskussionen af den marxistiske statsteori har spørgsmålet om den statslige fremstilling af materielle produktionsbetingelser udgjort et vanskeligt problem i forsøgene på at udvikle en sammenhængende forståelse af den kapitalistiske stat. De skyldes ikke mindst, at denne type af statsfunktioner ikke direkte kan sidestilles med en række andre statsfunktioner, hverken med hensyn til begrundelsessammenhæng eller med hensyn til historiske udviklingstræk.

Problemet består i at afklare den kapitalistiske stats funktion i forhold til en række af de materielle produktionsbetingelser såsom transportvæsen (jernbaner og vejanlæg), elektricitetsproduktion og -forsyning, post- og televæsen, telefonvæsnet, vandforsyning, rensningsanlæg, gasværker, naturgasanlæg, fjernvarmeanlæg, havnevæsen, o.s.v. ${ }^{1}$

En væsentlig del af disse områder har været og er stadig et anliggende for statsapparatet. Hvorfor det? Eller mere generelt: hvorfor drives en række produktioner af statsapparatet under en produktionsmåde, som iøvrigt domineres af kapitalistisk produktion, og med den hertil hørende private ejendomsret til produktionsmidlerne og den private tilegnelse af det samfundsmæssige overskudsarbejde?

1. Fastlæggelsen af de områder, som hører ind under de materielle produktionsbetingelser, og som tilvejebringes statsligt, er ikke en simpel sag; de nævnte områder er derfor kun eksempler. Sidenhen i artiklen behandles forskellige sider af den empiriske afgrænsning af de materielle produktionsbetingelser.

Det bør iøvrigt understreges, at stat og statsapparat i det efterfølgende anvendes i bred betydning. Hvis ikke andet er nævnt, skelnes der i det efterfølgende ikke mellem stat, amt og kommune. 
Hvori består den afgørende forskel mellem almindelig kapitalistisk produktion og statsvirksomhederne? Hvad er årsagen til de seneste års tilsyneladende $\emptyset$ gede tendenser til statsligg ørelsen af dele af produktionen? Er der nogle politiske perspektiver i statsliggørelsen af visse dele af produktionen, f.eks. af telefonvæsnet eller af dele af energiproduktionen? Og omvendt: er det frygten for statskapitalismen eller for socialisme ad bagdøren eller er det blot mangel på indsigt i egne interesser, som får borgerskabet til med alle midler at bekæmpe selv de mest begrænsede forslag vedrørende statsligg ørelse af olieproduktionen?

For overhovedet at kunne besvare denne type af spørgsmål er det nødvendigt nærmere at undersøge den rolle, som staten spiller i forhold til fremstillingen af dele af de materielle produktionsbetingelser.

Her står vi ikke på bar bund. Statsteoridiskussionerne bød - især i første halvdel af 1970'erne - på en række bidrag, hvor især bør nævnes bidragene fra Altvater, Läpple og Fester, som har indgået i den danske statsteoridiskussion, og som naturligvis fortsat bør inddrages.

I en forlængelse heraf er det artiklens formål dels at pege på disse bidrag og genoptage de tidligere diskussioner, dels at fremstille og kritisere det undersøgelsesprogram, der var indeholdt i de tidligere diskussioner af de almene materielle produktionsbetingelser, og dels at fremsætte et alternativt undersøgelsesprogram i et fors $\emptyset \mathrm{g}$ på at løse nogle af de problemer, som har været karakteristisk for de hidtidige løsningsfors $\emptyset \mathrm{g}$.

I artiklen gås der frem på følgende måde: Først behandles og kritiseres det statsteoretiske undersøgelsesprogram, som er indeholdt i de tidligere løsningsfors $\varnothing \mathrm{g}$ (afsnit 2 og 3). Dernaest diskuteres der, hvad der overhovedet skal forstås ved almene materielle produktionsbetingelser (afsnit 4). Slutteligt fremlægges de undersøgelsesmetoder, der må ses som et resultat af den opfattelse af de materielle produktionsbetingelser, som artiklen gør gældende (afsnit 5).

\section{De almene materielle produktionsbetingelser og det statsteoretiske undersøgelsesprogram}

I den marxistiske statsteoridiskussion har den umiddelbare baggrund for udviklingen af en teori om de almene materielle produktionsbetingelser været at kritisere og overskride det borgerlige infrastrukturbegreb. Her har spørgsmålet om, hvad der overhovedet skal forstås ved det »almene«, spillet en central rolle. 
Hvorfor er det vigtigt at vide, om nogle materielle produktionsbetingelser er almene til forskel fra andre, der kan karakteriseres som særlige eller specielle produktionsbetingelser?

Det hænger i hovedsagen sammen med, hvordan eksistensen af statsfunktionsfeltet - statslig tilvejebringelse af materielle produktionsbetingelser - er søgt begrundet. Groft taget har diskussionerne udviklet sig hen over følgende spørgsmål og svar. Spфrgsmål: hvorfor tilvejebringes visse produktionsbetingelser gennem statsapparatet; svar: fordi disse produktionsbetingelser er almene - det begrunder både produktionsbetingelsernes betydning for den kapitalistiske produktion og betingelserne for statsligg ørelsen af deres fremstilling. Spфrgsmål: hvad skal der forstås ved det »almene«. svar her kan noteres en række forskellige og delvis indbyrdes modstridende svar, som skal behandles i det efterfølgende.

Eller sagt på en anden måde: i diskussionerne er forholdet mellem stat og de materielle produktionsbetingelser blevet sammenfattet i det begrebsmæssige indhold af det »almene «. I en sådan fremgangsmåde bliver det temmeligt afg $\varnothing$ rende, hvad der overhovedet skal forstås ved det »almene«, idet fastlæggelsen af det »almene« på en og samme tid bliver en begrundelse for visse produktionsbetingelsers særlige betydning for kapitalens reproduktion og for statslig fremstilling eller i det mindste potentiel statslig fremstilling af de pågældende produktionsbetingelser.

Den centrale placering, som det »almene « har fået i statsteoridiskussionerne, har udmøntet sig i bestemte undersøgelsestrin, som kan opfattes som et statsteoretisk unders $\varnothing$ gelsesprogram i forhold til de almene materielle produktionsbetingelser. ${ }^{2}$ Dette undersøgelsesprogram kan opstilles således:

1. Hvorvidt har givne materielle produktionsbetingelser en særlig betydning eller ej for den kapitalistiske produktion. Dette undersøges direkte eller indirekte ved at tage stilling til om denne eller hin produktionsbetingelse er almen eller ej. Er den almen, så er den nødvendig eller har i det mindste en særlig betydning for den kapitalistiske produktion, for kapitalforholdets reproduktion, og/eller for kapitalakkumulationen.

2. Men hvad er almene materielle produktionsbetingelser for noget. Har det at gøre med den form, hvorigennem de tilvejebringes (Altvater), eller

2. I Inger Bonnesen \& Anne Thøger: Den kapitalistiske stat og dens funktioner; København 1975, s. 105-115 findes der en oversigt over de hidtidige diskussioner vedrørende staten og de almene materielle produktionsbetingelser. Deres oversigt kan samtidig ses som en implicit fremstilling af det statsteoretiske unders $\varnothing$ gelsesprogram, som her kritiseres. Se endvidere $I b$ Larsen: Miljøanlæg, Roskilde Universitetsforlag, 1976, som især diskuterer Läpple og Festers bidrag som grundlag for en realanalyse af udviklingen i rensningsanlægene, især s. 11-39. 
med den funktion (funktionelle nødvendighed) de har for den kapitalistiske produktion (Läpple), eller har det også noget at gøre med cirkulationsformen (den fælles brug) af de pågældende produktionsbetingelser (Fester).

3. Hvis de almene materielle produktionsbetingelser er nødvendige, og de ikke kan anlægges og/eller drives kapitalistisk, så må staten tilvejebringe og/eller drive dem.

De statsteoretiske opfattelser, som følger dette undersøgelsesprogram, har stort set alle taget udgangspunkt i det såkaldte vejbygningseksempel fra Marx (jvf. Karl Marx: Grundrids, Århus/København 1975, bd. 2, s. 393-401 og s. 561-565), men man er nået frem til forskellige opfattelser af de almene materielle produktionsbetingelser på basis af de samme citater.

For nærmere at belyse det nævnte statsteoretiske undersøgelsesprogram skal de tre vigtigste bidrag - fra Altvater, Läpple og Fester - behandles i forhold hertil. Formålet er ikke at give en nærmere teorihistorisk oversigt over bidragene, men at vise hvordan de falder ind under det anførte undersøgelsesprogram, og at påvise forskelle i opfattelsen af det »almene«, som også fører til forskelle i opfattelsen af det faktiske indhold af de produktionsbetingelser, som er til diskussion. Bidragene er fors $\emptyset$ gt sammenfattet i nogle få punkter, modsvarende opdelingen i det anførte undersøgelsesprogram. ${ }^{3}$ Punktopdelingen refererer til den logiske gang i undersøgelserne hos den pågældende.

Som en sidebemærkning til sin generelle statsteori behandler Altvater ${ }^{4}$ de almene materielle produktionsbetingelser; hovedsynspunkterne kan kort sammenfattes som følger:

- Altvater tager udgangspunkt i de funktioner, som ikke, ikke længere eller endnu ikke kan opfyldes af kapitalen. Eksempelvis: kommunikationssystem (gader og veje, kanaler, telegraf og post), uddannelsessystem, sundhedsvæsen, vandforsyning, kloakering og renovation, m.m. ${ }^{5}$

3. Sammenfatningen af de tre bidrag i nogle få punkter har her kun til formål at understrege den metodiske fremgangsmåde hos de pågældende, og yder i sagens natur ikke de tre forfattere fuld retfærdighed, hvad bidragenes eksakte indhold angår.

4. Elmar Altvater: Om nogle problemer ved statsinterventionismen, Kurasje nr. 7, s. 22-65; her refereres udelukkende til s. 35-40. Artiklen er genoptrykt i bogen Staten i det kapitalistiske samfund, Kurasje 1979, (samme sidehenvisning).

5. E. Altvater, op.cit., s. 36. Til de almene materielle produktionsbetingelser regner Altvater således også uddannelsessystem og sundhedsvæsen, men de kan dog næppe karakteriseres som materielle. Läpple kritiserer Altvater for det ved at sige: »En del af Altvater's vanskeligheder stammer fra, at han i begyndelsen korrekt går ud fra de almene materielle produktionsbetingelser, men begår den fejl gennem sit spring ind i empirien, at optage alle mulige andre områder i de almene produktionsbetingelser (f.eks. produktion, reproduktion 
- Grundene til, at de ikke kan anlægges og/eller drives kapitalistisk er vidt forskellige, men det skyldes $i k k e$ stoflige egenskaber. Det kan skyldes for stort kapitaludlæg, for lang omslagstid, mangel på varekarakter, for lille marked, for lav profitrate.

- Derfor overtager staten driften og/eller anlæg af de infrastrukturelle anlæg, som Altvater altså også kalder for almene materielle produktionsbetingelser.

På basis af en teori om de almene materielle produktionsbetingelser forsøger Läpple $e^{6}$ at udvikle en almen statsteori, som i princippet skal kunne omfatte alle statslige funktioner. I forhold til Altvater skærper Läpple indholdet af, hvad der skal forstås ved de almene materielle produktionsbetingelser: de er almene produktionsmidler (altså både arbejdsmidler og arbejdsgenstande), og må holdes adskilt fra arbejdskraftens almene reproduktionsbetingelser, som kræver en særlig undersøgelse, og som Läpple ikke behandler. Om de almene materielle produktionsbetingelser siger han følgende:

- Almene materielle produktionsbetingelser har intet at gøre med, hvem der anlægger og/eller driver dem, om det er staten eller kapitalen spiller ingen rolle (kritik af Altvater, jvf. det første punkt hos ham).

- Om produktionsbetingelser er almene eller ej er alene et spørgsmål om deres funktion i den samfundsmæssige produktionsproces. Det almene skyldes, at disse produktionsbetingelser ikke er indeholdt i en særlig produktionsproces, men fungerer som forbindelsesled mellem en masse særlige kapitalers produktionsprocesser.

- Med den tiltagende samfundsmæssiggørelse af produktionen bliver stadig mere omfattende almene produktionsbetingelser nødvendige. De almene produktionsbetingelser er et specifikt resultat af den kapitalistiske produktions specifikke udvikling, og bliver til et væsentligt område i de statslige aktiviteter, men er ikke nødvendigvis et statsligt anliggende. Det er derimod den kapitalistiske produktionsmådes almene ydre betingelser (retsforholdene), som staten tilvejebringer og sikrer uafhængigt af en given udviklingsfase i den kapitalistiske produktionsmåde.

og »reparation « af arbejdskraften, den immaterielle produktion o.s.v.).«; jvf. Dieter Läpple: Staten og de almene produktionsbetingelser; København 1973, s. 72-73.

6. Dieter Läpple: Staten og de almene produktionsbetingelser; København 1973, specielt kapitel 3: »De almene materielle produktionsbetingelsers begreb, « heraf s. 72-80. De nedenfor anførte punkter findes delvis modsvarende hos Läpple, opstillet i punkterne a-e, s. 74-75. 
Hvor det »almene « hos Altvater var en sammenfatning af manglende betingelser for kapitalistisk produktion indenfor de pågældende områder $o g$ den statsliggjorte fremstilling af dem, er Läpples standpunkt, at »... Bestemmelsen - at være almene produktionsbetingelser - følger ene og alene af deres funktion i den samfundsmæssige produktionsproces. $\ll^{7}$ Denne opfattelse af det »almene « er et vigtigt kritikpunkt hos Fester.

Festers bidrag ${ }^{8}$ er i hovedsagen en uddybning og kritik af Läpples problemstillinger. For det første mener Fester, at bestemmelsen af det »almene« ikke blot skal omfatte produktionsbetingelserne, men også arbejdskraftens reproduktionsbetingelser. »Det drejer sig derfor om at bestemme det »almene « $\mathrm{i}$ forbindelse med disse almene betingelser $\mathrm{i}$ et begreb, som gælder både for de almene produktionsbetingelser og for arbejdskraftens almene reproduktionsbetingelser. « For det andet kan det »almene« ikke bestemmes udfra de pågældende betingelsers funktion i den samfundsmæssige reproduktionsproces, men derimod i det særlige ved deres form, ${ }^{10}$ hvor det særlige ved forbrugsformen er $» . .$. virksomheders eller individers kollektive konsumering af dem. ${ }^{11}$ Ved kapitalistisk produktion fører den særlige forbrugsform til en specifik cirkulationsmåde.

I det følgende skal Festers synspunkter alene vedrørende de almene produktionsbetingelser, som han også kalder for almene arbejdsmidler, sammenfattes i punktform:

- Kriteriet for det »almene« i de almene produktionsbetingelser skal ikke $s \emptyset$ ges i deres funktion i den samfundsmæssige produktionsproces (kritik rettet mod Läpple), men i en formbestemmelse, der er baseret på brugsværdiens konsumtionsmåde. ${ }^{12}$

- De almene produktionsbetingelser skal forstås som almene arbejdsmidler, som forbruges af forskellige kapitaler på samme tid som fælles betingelse for deres produktion og cirkulation. De er ikke indeholdt i den særlige (specifikke) produktionsproces, men fremstår som fælles betingelse for en masse sådanne specifikke produktionsprocesser. ${ }^{13}$

7. D. Lapple, op.cit., s. 74.

8. Marc Fester: »Infrastruktur«, og kapitalvalorisering. Kritik af D. Läpples »Staten og de almene produktionsbetingelser «, Kurasje nr. 12, s. 96-125.

9. M. Fester, op.cit., s. 98.

10. M. Fester, op.cit., tese s. 99.

11. M. Fester, op.cit., s. 100.

12. M. Fester, op.cit., tese, s. 99, som også omhandler arbejdskraftens almene reproduktionsbetingelser med tilsvarende formuleringer.

13. M. Fester, op.cit., tese, s. 105. 
- Ved en kapitalistisk drift af de almene produktionsbetingelser gælder det, at de almene arbejdsmidler ikke er varer, men antager form af fixkapital, som cirkulerer i en særlig form, nemlig som lejebærende kapital, som fungerer efter den rentebærende kapitals form. ${ }^{14}$

- Indenfor mange områder begrænser den kapitalistiske drift en udvikling i de almene produktionsbetingelsers omfang som følge af den (ovenfor nævnte) særlige cirkulationsform. Denne begrænsning bliver en skranke for en masse andre kapitalers akkumulation, og den danner grundlag for statsliggørelsen af de almene produktionsbetingelser. ${ }^{15}$

Som det fremgår af oversigten, består den væsentligste forskel mellem Altvater, Läpple og Fester i, hvad der bliver forstået ved det »almene«. I de øvrige prolemstillinger gør der sig kun de forskelle gældende, som er en følge af den forskellige opfattelse af det »almene«; det viser sig bl.a. ved afgrænsningen af, hvilke produktionsbetingelser der er til undersøgelse.

Hos Altvater er de almene materielle produktionsbetinglser direkte forbundet med statsliggørelsen; hos Läpple og Fester er henholdsvis de almene materielle produktionsbetingelser og de almene produktionsbetingelser ikke nødvendigvis statsliggjorte, men det er deres karakter af at være almen, som kan fremtvinge en statsliggørelse.

Det vigtige i denne sammenhæng er, at de alle tre arbejder indenfor det samme statsteoretiske undersøgelsesprogram, hvor fastlæggelsen af det »almene« er af en helt dominerende betydning. Denne tilgang skal forsøges kritiseret i det følgende.

14. M. Fester, op.cit., s. 106-107 og 109.

15. M. Fester, op.cit., s. 117, samt s. 119-123. I spørgsmålet om statsliggørelsen af de almene produktionsbetingelsers fremstilling afgrænser Fester sig fra Altvater og Läpple på følgende måde: »I modsætning til Altvater, som på en 'råempirisk' måde angiver den manglende profitabilitet ved de almene produktionsbetingelser som årsag til statsliggørelsen, søger Läpple disse årsager i det almene arbejdsmiddels lave valoriseringsgrad i stedet for at rejse spørgsmålet om årsagerne til den manglende profitabilitet.«; M. Fester, op.cit., s. 118. Det kan ikke, siger Fester, være et spørgsmål om merværdiproduktionens størrelse (valoriseringsgrad) indenfor det pågældende produktionsområde; metodisk må man tage udgangspunkt i den manglende profitabilitet; statsligg ørelsen er forbundet med undergennemsnitlig profitabilitet som følge af mangel på betalingsdygtig eftersp $\emptyset$ rgsel, som Fester ser som en hindring for dannelse af produktionsprisen og dermed som en hindring for etablering af en gennemsnitlig profitabilitet indenfor det pågældende produktionsområde. Heraf følger statsliggørelsen. 


\section{Brudstykker af en kritik}

De tre forfattere har en afgørende lighed. Som tidligere nævnt baserer de deres forståelse af de almene materielle produktionsbetingelser på det såkaldte vejbygningseksempel, hvor Marx behandler vejbygning, kanaler, jernbane, m.v., altså transportmidlerne. På forskellig vis prøver de tre forfattere at generalisere bestemmelserne vedrørende transportmidlerne til at omfatte alle former for almene produktionsbetingelser.

Altvater generaliserer forholdene omkring kapitalens anlægsstørrelse ved vejbygning (mangel på profitable anlægs- og driftsbetingelser) til at være et alment træk ved det, der skal forstås som almene materielle produktionsbetingelser. Derfor er de almene materielle produktionsbetingelser hos Altvater altid statsliggjorte, eller i det mindste tilvejebragt udenfor den kapitalistiske produktionsproces.

Läpple generaliserer udfra vejenes funktion (nødvendige forbindelsesled mellem særlige produktionsprocesser, m.v.) til, at det må gælde for alle almene materielle produktionsbetingelser; de må være »forbindelsesled « $i$ en eller anden forstand. ${ }^{16}$

Og Fester generaliserer udfra forbrugsformen af kommunikationsog transportmidlerne og deres værdicirkulation til, at almene produktionsmidler (eller almene arbejdsmidler, som han foretrækker at kalde dem) er dem, som forbruges og hvor værdien cirkulerer på samme måde som ved jernbaner, veje, etc. De almene arbejdsmidler er kollektivt konsumeret arbejdsmidler. ${ }^{17}$

Flatow og Huisken, ${ }^{18}$ hvis statsteoretiske bidrag iøvrigt ikke er anvendeligt i denne sammenhæng, kritiserer i en sidebemærkning forsøgene på at generalisere udfra vejbygningseksemplet. En almen teori om de almene materielle

16. Läpple opnår generaliseringen ved at opfatte de almene materielle produktionsbetingelser som kun de produktionsmidler, der fungerer som forbindelsesled mellem de forskellige produktionsprocesser, og bygger denne opfattelse på et citat fra Grundrids (jvf. note 17).

17. Fester opnår generaliseringen ved i et citat fra Grundrids (op.cit., s. 564, tysk udgave s. 613) at ombytte Marx's »forbindelsesled « med »fælles betingelse «. I Festers note 26 hedder det: »For at få en almen formulering har vi erstattet Marx's »forbindelsesled « med »fælles betingelse«; Fester, op.cit., s. 105 (min forhævelse). Det er udtrykket »forbindelsesled«, som får Läpple til på basis af det samme Marx-citat at hævde en funktionsbestemmelse af det »almene«. Det er vigtigt at understrege, at denne kritik kun retter sig mod Festers generalisering fra kommunikations- og transportmidlernes særlige fixkapitalform og cirkulationsform til enhver bestemmelse af de almene produktionsbetingelser. Kritikken går ikke på, at specifikke former for produktionsbetingelser kan have en sådan leje-/rentebærende form, men på at det ikke kan forudsættes som et generelt træk.

18. Sybille von Flatow \& Freerk Huisken: Den borgerlige stats afledningsproblem, II, Kurasje nr. 10, s. 4-55; her kun siderne 43-55. 
produktionsbetingelser, siger de, kan ikke opstilles på dette grundlag. Flatow $\&$ Huiskens kritikpunkter kan resumeres nogenlunde som følger.

Det er ikke tilfældigt - siger Flatow \& Huisken - at Marx i det hyppigt citerede Grundridsafsnit taler om vejbygning, kanaler, jernbaner, m.v. Hans undersøgelse drejer sig nemlig om transport og kommunikationsmidler. Marx undersøger især to ting i afsnittet: hører transporten med til produktionstiden eller cirkulationstiden; dette spørgsmål har betydning for transportarbejdets rolle i kapitalens værdiforøgelsesproces. Og under hvilke betingelser må den borgerlige stat træde ind i produktionen af transportmidlerne, og under hvilke betingelser bliver denne til en profitmæssig anlægssfære for kapitalen.

Derfor kan man ikke uden videre erstatte »vejbygning, kanaler, jernbaner, m.v.« med »uddannelse, sundhedsvæsen, miljøbeskyttelse, socialforsorg, politik, o.s.V.«. Marx’s problemstillinger såvel som undersøgelsesresultater kan ikke direkte overføres til andre områder, ikke mindst i betragtning af, at der for en del af de statsfunktionsfelter, som ad denne vej forsøges indplaceret som almene materielle produktionsbetingelser, slet ikke er tale om materielle produktionsbetingelser.

I diskussionen af, hvorfor visse produktionsbetingelser tilvejebringes gennem statsapparatet, og i kritikken af Altvater, har Läpple og Fester fastholdt den oprindelige hensigt med at klarlægge, hvilke produktionsbetingelser, der kan karakteriseres som »almene«. Nemlig at udfylde følgende tankegang: almene produktionsbetingelser har en særstilling i den kapitalistiske produktionsproces (forbindelsesled, fælles anvendelse); denne særstilling gør, at der er grænser for disse produktionsbetingelsers kapitalistiske fremstilling. Med en eksplicit henholdsvis implicit antagelse om de almene produktionsbetingelsers nødvendighed fører det hos Läpple og Fester til, at de almene produktionsbetingelser må tilvejebringes gennem statsapparatet, når grænsen for deres kapitalistiske fremstilling nås. (Gennem sit begreb for det »almene « antager Altvater det, der skal forklares, nemlig statsliggørelsen).

Det frister til en forkortet problemstilling: hvis noget kan karakteriseres som almene produktionsbetingelser, så er deres tilvejebringelse statsliggjort eller så udg $ø$ r de et potentielt statsindgrebsfelt. Statsanalysen - d.v.s. analysen af statsliggørelsen - bliver på denne måde reduceret til en stillingtagen til, hvorvidt denne eller hin produktionsbetingelse er almen eller ej. Er den almen, så er der efter denne opfattelse på én og samme tid leveret en forklaring på de pågældende produktionsbetingelsers betydning for den kapitalistiske produktion og nødvendigheden af deres statsliggjorte fremstilling.

Det er en kritisabel forkortelse af analysen af den statsliggjorte tilvejebringelse af materielle produktionsbetingelser. Forkortelsen skyldes - som 
tidligere nævnt - at forholdet mellem stat og de materielle produktionsbetingelser søges sammenfattet i ét begreb - det »almene «, der forudsættes at dække enhver tænkelig relation mellem stat og de materielle produktionsbetingelser.

Et sådant undersøgelsesprogram må kritiseres på i det mindste tre punkter: en manglende differentiering mellem de materielle produktionsbetingelsers forskellighed; mangler i behandlingen af de historiske udviklingstræk (statsliggørelse/reprivatisering); og en uklar eller mangelfuld inddragelse af produktionsbestemmelsen i analysen af de materielle produktionsbetingelsers produktion.

En manglende differentiering mellem de materielle produktionsbetingelsers forskellighed er allerede kritiseret i det foregående ved bemærkningerne om generaliseringen udfra kommunikations- og transportmidlerne. Alle de materielle produktionsbetingelser, som tilvejebringes af statsapparatet, lader sig langt fra forstå som et spørgsmål om »forbindelsesled « eller »fælles brug «. Vand f.eks. er en materiel produktionsbetingelse; den tilvejebringes af statsapparatet (omend ikke udelukkende); den lader sig under ingen omstændigheder forstå som »forbindelsesled«, og den forbruges ej heller i fællesskab. Generaliseringen udfra kommunikations- og transportmidlerne fører til en for snæver bestemmelse af de materielle produktionsbetingelser.

Mangler i behandlingen af de historiske udviklingstræk udfra en bestemmelse af det »almene« ved givne produktionsbetingelser viser sig især i forholdet mellem statsliggørelses- og reprivatiseringstendenser. Läpples »forbindelsesled « og Festers »fælles brug « er en karakteristik af den pågældende brugsværdis funktion i en given produktionsproces. ${ }^{19}$ Det er en stoflig bestemmelse, og som sådan er den invariant overfor kapitalismens historiske udvikling. Enten betyder det en manglende mulighed for at forklare de faktisk forekommende historiske skift mellem statsligg ørelse henholdsvis reprivatisering og blandingsformerne, eller også fører det til, at bestemmelsen af givne produktionsbetingelser som almene bliver helt overflødige. ${ }^{20}$

19. Forskellen mellem Läpple og Fester er den, at Läpple bliver stående ved funktionsbestemmelsen, medens Fester fører sin funktionsbestemmelse videre over i en bestemmelse af cirkulationsformen.

20. Det første er tilfældet for Läpple, som i de formuleringer han giver, overvejende antager en stigende almengørelse og stigende statsliggørelse; hans begrebsapparat kan ikke begribe de faktiske historiske udviklingstræk. Hos Fester er det »almene« også invariant bestemt; det der historisk kan variere er dels de pågældende produktionsbetingelsers omfang og deres statsliggørelse; følgelig er forbindelsen mellem det invariante at være »almen« og de historiske konsekvenser heraf skåret over. 
Den uklare eller mangelfulde inddragelse af produktionsbestemmelsen viser sig ved, at den kapitalistiske produktionsproces og de lovmæssigheder, der regulerer dens udvikling, ikke inddrages systematisk i undersøgelserne, og under ingen omstændigheder danner det systematiske udgangspunkt for unders $\emptyset$ gelserne.

Produktion er også produktion af produktionsbetingelser. Fremfor at betragte produktionsbetingelserne med udgangspunkt i deres placering i efterfølgende produktioner som en funktionel nødvendighed (Läpple) eller som en kollektivt konsumeret størrelse (Fester), altså fremfor at betragte givne produktionsbetingelser efter deres forbrug, bør udgangspunktet være at betragte dem som producerede betingelser. D.v.s. det systematiske udgangspunkt bør være den produktionsproces, hvorigennem givne produktionsbetingelser fremstilles. Det er karakteren af denne produktionsproces, som er afgørende for statsliggørelsestendenser, og ikke forbrugsformen af denne produktionsprocesses arbejdsprodukter.

\section{De materielle produktionsbetingelser}

I det foregående er der forsøgt en kritik af, at det »almene« er blevet gjort til en formidlingskategori for forholdet mellem stat og materielle produktionsbetingelser. I dette afsnit skal det undersøges, om der overhovedet meningsfuldt kan tales om noget som almene materielle produktionsbetingelser, set i forhold til den kapitalistiske produktionsproces. Først behandles de materielle produktionsbetingelser, dernæst unders $\varnothing$ ges forholdet mellem »almene « og særlige materielle produktionsbetingelser. Som det tredie behandles spørgsmålet om den kapitalistiske fremstilling af de materielle produktionsbetingelser.

\subsection{Materielle produktionsbetingelser}

De materielle produktionsbetingelser er de materielle bestanddele, som indgår i den umiddelbare produktionsproces som betingelse for dens gennemførelse. Hvad dette indebærer skal kort uddybes.

Den kapitalistiske produktionsproces kan som bekendt oversigtsmæssigt karakteriseres således:

$\mathrm{P}-\mathrm{V}<\frac{\mathrm{AK}}{\mathrm{PM}}>\mathrm{V}^{\prime}-\mathrm{P}^{\prime}$ 
hvor $(\mathrm{P})$ er penge, som gennem køb forvandles til vareværdier $(\mathrm{V})$ af to hovedtyper: arbejdskraft og produktionsmidler (arbejdsgenstande og arbejdsmidler), som dernæst gennem produktionen forvandles til værdimæssigt set flere varer (V'), som slutteligt gennem salget forvandles til flere penge (P'). Den umiddelbare produktionsproces har således tre hovedbestanddele: arbejdskraft, arbejdsmidler og arbejdsgenstande.

Det er selvklart, at den umiddelbare produktionsprocesses arbejdsmidler og arbejdsgenstande er materielle størrelser. Men det kan diskuteres, hvordan arbejdskraften skal forstås i denne sammenhæng.

Omend arbejdskraften er en materiel kraft, så er den ikke en materiel størrelse på linie med arbejdsmidler og arbejdsgenstande; det kan man til nød hævde, at arbejderen er, men han indgår (forhåbentlig) ikke i selve produktionens materielle bestanddele. Ved sin deltagelse i den umiddelbare produktionsproces overfører arbejderen sin arbejdskraft på arbejdsgenstanden, d.v.s. arbejdskraften materialiseres i produktionens produkter.

Den materielle reproduktion af arbejderen eller rettere af hele arbejderklassen er en forudsætning for et fortsat $k \varnothing b$ og anvendelse af arbejdskraften i den kapitalistiske produktion. I modsætning til arbejdsmidlernes og arbejdsgenstandenes produktion/reproduktion så finder arbejderklassens materielle reproduktion ikke sted som en kapitalistisk produktionsproces, men formidles over den »lille cirkulation «, d.v.s. som $k \varnothing b$ af reproduktionsmidler efter forudgående salg af arbejdskraften efter formen V-P-V, i modsætning til den kapitalistiske produktion/reproduktion, som altid har formen: P-V-P.

Arbejderklassens materielle reproduktion er en produktionsbetingelse for den umiddelbare produktionsproces, men denne produktionsbetingelse kan næppe karakteriseres som en materiel produktionsbetingelse af samme art, som det der gør sig gældende for arbejdsmidler og arbejdsgenstande. Hertil kommer de forskellige former, hvorigennem de frembringes. Det betyder følgende: selvom visse områder af arbejderklassens materielle reproduktion gennem statsliggørelsen udviser lighedstræk med de materielle produktionsbetingelser, så kan disse reproduktionsområder ikke ligestilles med eller unders $\emptyset$ ges på samme måde som de produktionsbetingelser, som er en direkte materiel bestanddel af den umiddelbare produktionsproces.

I det følgende skal kun de produktionsbetingelser behandles, som indgår som materielle bestanddele af den umiddelbare produktionsproces, altså arbejdsmidler og arbejdsgenstande, hvis forskellige dele skal undersøges nærmere.

Figuren har til formål at vise, at produktionens forskellige materielle bestanddele og derfor dens materielle produktionsbetingelser i forskellig ud- 
FIGUR 1. Den umiddelbare produktionsprocesses materielle bestanddele.

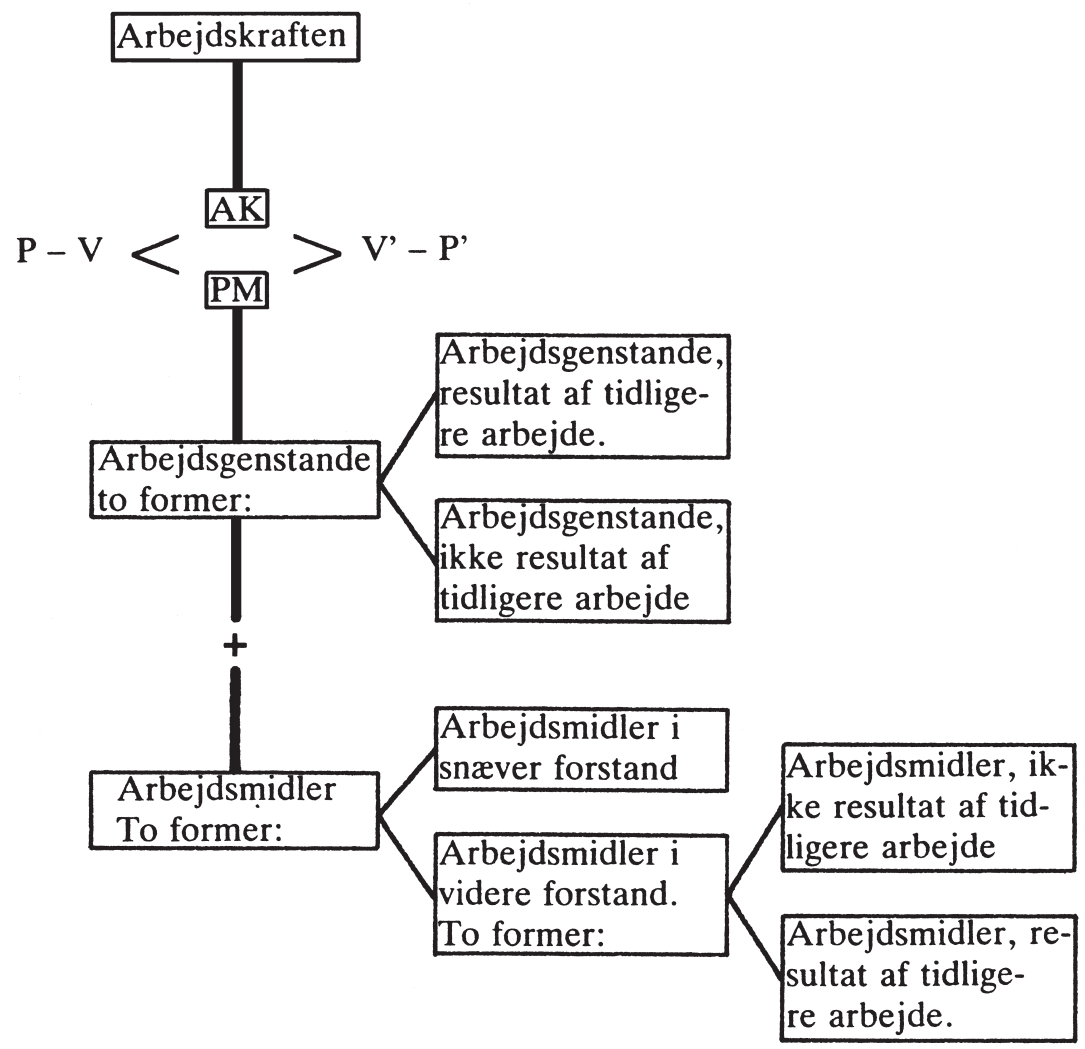

strækning er et resultat af tidligere arbejde; under fuld udviklet kapitalisme vil det sige: resultat af en forudgående kapitalistisk produktion. Det skal kort gennemgås nærmere. ${ }^{21}$

Arbejdsmidlerne kan deles $\mathrm{i}$ to hovedformer: arbejdsmidler $i$ snaever forstand, som er redskaber, værkt $\varnothing \mathrm{j}$, maskiner, m.v., som direkte bruges ved over-

21. Figurens begrebsopdeling og den efterfølgende begrundelse stammer delvis fra Karl Marx: Kapitalen, København 1970, bd. 1:2, s. 302-312. 
førsel af arbejde til arbejdsgenstanden. Og arbejdsmidler $i$ videre forstand, som er arbejdsmidler der ikke direkte indgår i processen, men som er alle de objektive betingelser der i det hele taget skal være opfyldt, for at produktionsprocessen kan finde sted.

Alle arbejdsmidler i snæver forstand er resultat af tidligere arbejde; det gælder derimod ikke for alle arbejdsmidler i videre forstand.

Som eksempel på arbejdsmidler, der er resultat af tidligere arbejde, kan nævnes værksteder, fabriksanlæg, kanaler, veje, jernbaner, o.s.v. Af arbejdsmidler, der ikke er resultat af tidligere arbejde, er jorden den vigtigste, idet den skaffer arbejderen et ståsted og et virkefelt for processen; af andre kan nævnes vandløb til transport og bortskaffelse af produktionens ekskrementer, som typisk i begyndelsen anvendes uden tilsætning af arbejde; stigende anvendelse og dermed vandløbsforurening gør det nødvendigt at tilsætte arbejde til oprensning for at vandløbet fortsat kan fungere som arbejdsmiddel i videre forstand.

På linie hermed kan arbejdsgenstandene ligeledes opdeles i de arbejdsgenstande, som er resultat af tidligere arbejde, og de arbejdsgenstande, som ikke er det, men som forekommer umiddelbart i naturen. Det sidste gælder kun den extraktive industri (minedrift m.v., jagt og fiskeri); alle andre industrier behandler arbejdsgenstande, der tidligere er forarbejdet, d.v.s. arbejdsgenstande der er et arbejdsprodukt.

Hovedparten af produktionens arbejdsgenstande er således resultat af tidligere produktion; det er det samme som, at produktionen også er produktion af produktionsbetingelser. I den udstrækning produktionen er kapitalistisk, fremstilles produktionens produktionsbetingelser følgelig også kapitalistisk.

I tillæg til ovenstående opdeling (jvf. fig. 1) er det vigtigt at understrege, at det ikke er tingslige egenskaber, som afgør, hvorvidt en given brugsværdi er arbejdsgenstand, arbejdsmiddel eller arbejdsprodukt. Det afhænger alene af brugsværdiens funktion i arbejdsprocessen; i en arbejdsproces kan et produkt være arbejdsgenstand, for i en efterfølgende arbejdsproces at være arbejdsmiddel, ligesom et givet råmateriale kan gennemløbe en række produktionstrin, og derfor skiftevis optræde som arbejdsprodukt, arbejdsgenstand og/eller arbejdsmiddel; o.s.v.

\subsection{Almene materielle produktionsbetingelser?}

Hovedspørgsmålet er, om der overhovedet meningsfuldt kan fastlægges et begreb, som omfatter sådan noget som: almene materielle produktionsbetingelser. Kan produktionsbetingelser på én gang både være almene og så være 
de materielle bestanddele og dermed være de mangfoldige brugsvardier, som indgår i produktionen i snæver og videre forstand.

Da de materielle produktionsbetingelser er produktionens materielle bestanddele, så kunne man som følge heraf hævde, at almene materielle produktionsbetingelser er de materielle bestanddele, som er alment forekommende i produktionen, som forekommer som fælles betingelser, eller som forekommer som elementære betingelser for produktionen. Det er imidlertid en kritisabel opfattelse.

Produktions- og Raastofkommissionen anvender i deres 1942-betænkning et produktionsbetingelsesbegreb, som modsvarer denne opfattelse; de siger: »Udvalget er principielt af den opfattelse, at staten fortrinsvis bør bekoste de forskningsopgaver, der vedrører tilvejebringelsen af de elementore produktionsbetingelser, således foruden teknikeres og arbejderes uddannelsesmæssige standard, også elementære råstoffer, kraft, varme, transportmuligheder og lignende $\ldots \ll{ }^{22}$

Elementære råstoffer, kraft, varme, transportmuligheder og den uddannelsesmæssige standard er således efter denne opfattelse elementære produktionsbetingelser - eller almene produktionsbetingelser.

Begreb af samme karakter genfindes mere eller mindre hos Läpple og Fester; det er indeholdt i deres begreber »fælles produktionsbetingelser « henholdsvis »fælles arbejdsmidler«, som er betingelser/midler af en vis almen nødvendighed.

Elementær - fælles - almen - o.s.v. er bestemmelser, som er en abstraktion fra det særegne, og som har til formål at fremhæve eller fiksere det, der er fælles for al produktion. Taler vi om den kapitalistiske produktion er der visse abstraktioner, som er mulige og nogle som er umulige eller meningsløse.

Det er muligt at abstrahere fra produktionens stoflige side for at fremhæve det, som al kapitalistisk produktion har fælles, nemlig produktion af merværdi. På grundlag af de almene bestemmelser (værdiloven, den generelle akkumulationslov, o.s.v.) er det naturligvis muligt at fastslå de almene produktionsbetingelser, d.v.s. almene betingelser for produktion af merværdi; men sådanne bestemmelser vil netop ikke inkludere det materielle eller det stoflige; det blev der jo abstraheret fra som en forudsætning for begribelse af den kapitalistiske produktion som produktion af merværdi.

Omvendt er det imidlertid ikke muligt at gennemføre den omvendte abstraktion. Det er ikke muligt at abstrahere fra produktionens værdimæssige

22. Betænkning angående Teknisk-videnskabelig Forskning; Produktions- og Raastofkommissionen, København 1942, s. 22. Optrykt i TEK/SAM-grundkursus 79/80 (Produktion og Stat i perioden 1900-79), bd. III, s. 131. 
side og fra produktionens specifikt forskellige materielle bestanddele med det formål at fremhæve materielle bestanddele, som må anses for fælles for al produktion (kapitalistisk eller ej - det gør ingen forskel), fordi enhver produktions materielle betingelser eller materielle bestanddele er så mangfoldige og forskellige, at det ikke meningsfuldt ville være muligt at fremhæve bestemte materielle bestanddele som alment forekommende eller alment nødvendige.

Det hænger sammen med, at der ikke findes nogen almen produktion eller produktion i almindelighed. Produktionen er altid en særlig produktionsgren. Derfor findes der heller ikke almene materielle produktionsbetingelser, men kun sarlige materielle produktionsbetingelser, svarende til de særlige produktionsgrene. ${ }^{23}$

Specielt Fester har uden tvivl gjort sig disse problemstillinger klart, selvom han bliver hængende i problemstillingen, hvad angår almengørelse af de særlige materielle produktionsbetingelser. Det ses især af følgende. I sit almene produktionsbetingelsesbegreb udelukker han følgende bestanddele af produktionens betingelser: arbejdskraft, arbejdsgenstande, og arbejdsmidler i snæver forstand. Han koncentrerer sig udelukkende om arbejdsmidler i videre forstand, d.v.s. de materielle eller objektive betingelser, som skal være opfyldt for at produktionen kan finde sted, men som ikke direkte indgår i arbejdsprocssen. Indenfor dette område - arbejdsmidler i videre forstand afgrænser Fester sig til de objektive betingelser, som er fælles betingelser for en række kapitaler. De almene produktionsbetingelser bliver således afgrænset til de fælles arbejdsmidler i videre forstand. ${ }^{24}$

Men ikke nok med det. For det andet bestemmer han de almene produktionsbetingelser som en ren tautologi for ikke at ende i modsigelsen mellem det almene og det materielt specifikke: med det almene forstås ikke fælles træk, fælles forhold, m.v., men derimod fælles brug. Almene materielle produktionsbetingelser er arbejdsmidler, som forbruges i fællesskab af en række kapitaler,

23. Jvf. indledningen til Karl Marx: Grundrids, Århus/København 1974, s. 5-10; her behandles forholdet mellem almen og særegen især i forhold til de såkaldte almene betingelser for produktionen. Det hedder her (s. 10): »Der findes bestemmelser, der er fælles for alle produktionstrin og som af tænkningen fikseres som almene; men de såkaldte almene betingelser for al produktion er intet andet end disse abstrakte momenter, hvormed intet virkeligt historisk produktionstrin er begrebet«; (fremhævelserne delvis mine).

24. Det må nødvendigvis præciseres, at der her blot er tale om et sammenfald mellem almene produktionsbetingelser og arbejdsmidler i videre forstand. Fester kritiserer således Läpple for en sammenblanding af de middelbare arbejdsmidler, d.v.s. arbejdsmidler i videre forstand med de almene arbejdsmidler, jvf. Fester, op.cit., s. 101. Der er dog en indirekte sammenhæng, som Fester ikke gør klart; efter sin bestemmelse som en særlig konsumtionsform henholdsvis cirkulationsform kan de almene arbejdsmidler hos Fester næppe være andet end arbejdsmidler i videre forstand. 
som ikke siger andet end, at det almene er fælles brug, og fælles brug er det almene..$^{25}$

Argumentationen i det foregående har gået på, at det ikke er muligt at fremhæve bestemte materielle produktionsbetingelser som almene udfra deres brugsværdi, anvendelsesmåde (herunder cirkulationsform), m.v.; altså som materielle produktionsbetingelser, der har en almen betydning for produktionen.

Argumentationen går også på, at det er uden betydning, hvorvidt materielle produktionsbetingelser kan karakteriseres som almene eller ej. Interessen i at fastslå, hvorvidt denne eller hin materielle produktionsbetingelse er almen eller ej, er som tidligere nævnt udelukkende et resultat af det specifikke statsteoretiske undersøgelsesprogram, som tidligere er kritiseret.

Selvom enhver materiel produktionsbetingelse må forstås som en specifik (eventuelt branchespecifik) produktionsbetingelse, så betyder det ikke, at tilvejebringelsen af de specifikke materielle produktionsbetingelser ikke kan have en afgørende betydning for den samlede produktion eller for dele af den samlede produktion, og derfor være genstand for statslig anlæg/drift i den udstrækning de pågældende produktionsbetingelser ikke kan fremstilles eller ren faktisk fremstilles kapitalistisk.

Hvis vi forudsatte, at der i et land kun fandtes en produktionsgren, så ville denne produktionsgrens specifikke materielle produktionsbetingelser - det kunne f.eks. være et bestemt råstof - fremstå som det eneste og dermed en almen materiel produktionsbetingelse, ikke som følge af specifikke egenskaber ved den pågældende brugsværdi, men derimod som et resultat af det pågældende lands produktionsstruktur. Det var i såfald produktionsstrukturen, som havde almengjort en specifik materiel produktionsbetingelse. Almengørelse ville således være et specifikt historisk resultat af produktionsstrukturens udvikling, og ikke noget der var almengyldigt, givet til enhver tid for ethvert kapitalistisk land.

En række produktionsgrene kan i større eller mindre udstrækning have de samme materielle produktionsbetingelser, f.eks. vil jern- og metalindustrien have produktion (og cirkulation) af råjern som en fælles materiel produktionsbetingelse. Denne omstændighed har ført til, at fremstillingen af råjern (stålog valseværker) hyppigt opfattes som basisindustri; det er et upræcist begreb,

25. Hermed har begrebet »almen« mistet sin specifikke betydning; der er ikke længere tale om en fælles bestemmelse i begrebsmæssig modsætning til særegne eller specifikke bestemmelser, men derimod, at der med ordet almen forstås fælles brug. 
som dækker over, at produktion af råjern er produktion af produktionsbetingelser for jern- og metalindustrien. Basisindustribetragtningen var grundlaget for, at staten i 1930'erne deltog i oprettelse (anlæg) af Det danske Stålvalseværk; gennem anvendelsen af skråtjern ville det sikre mere gunstige og stabile produktionsbetingelser for den danske jern- og metalindustri, som på dette tidspunkt udgjorde knap 29\% af hele den industrielle produktion.

Udvikling af kraftmaskinen samt energien (brændsel, elektricitet) til kraftmaskinerne fremstår på samme måde som en fælles materiel produktionsbetingelse for en række industrier. Fremstilling af elektricitet bliver eksempelvis således en mere og mere nødvendig produktionsbetingelse for et større og større antal industrier med en stigende anvendelse af elektromotorer og en stigende anvendelse af elektricitet som procesenergi.

Produktionen af transportmidler og produktion af transportarbejde fremstår på tilsvarende måde som en materiel produktionsbetingelse for en række industrier, hvis betydning som materiel produktionsbetingelse vokser med den stigende samfundsmæssige arbejdsdeling og verdensmarkedets voksende betydning.

\subsection{De særlige materielle produktionsbetinglser og deres kapitalistiske fremstilling}

Produktion er også produktion af produktionsbetingelser; gennem produktionen tilvejebringes den lange række af specifikke materielle produktionsbetingelser, som er nødvendige for de enkelte produktioner.

Betingelser for produktionen af de specifikke materielle produktionsbetingelser er derfor de betingelser, som gælder for enhver produktion: nødvendig akkumulation og nødvendig profitabilitet.

Den nødvendige akkumulation er et spørgsmål om tilvejebringelse af den minimumskapital, som er nødvendig for anlæg af en given produktion. Tilstedeværelsen af de nødvendige akkumulationspotentialer hænger sammen med den kapitalistiske produktionsmådes udviklingsgrad; jo mere udviklet kapitalisme, jo større akkumulationspotentialer i kraft af en fortløbende koncentration af kapital eller centralisering af eksisterende kapitaler. (»Vi ville endnu være uden jernbaner, hvis vi skulle have ventet, indtil akkumulationen havde bragt nogle enkeltkapitaler så vidt, at de kunne magte at bygge en jernbane. Centralisationen har kunnet præstere dette i en håndevending, takket være aktieselskaberne «). ${ }^{26}$ Akkumulationspotentialernes tilstedeværelse hæn- 
ger også sammen med akkumulationens fordeling på de forskellige produktionsområder; denne fordeling hænger igen sammen med profitabiliteten for et givet produktionsområde i forhold til andre produktionsområder.

Den nødvendige profitabilitet skal ikke forstås absolut, men derimod relativt. Det er et spørgsmål om profitratens størrelse for et givet produktionsområde i forhold til den samfundsmæssige gennemsnitlige profitrate.

Kapitalens fordeling på de enkelte produktionsgrene er ikke bestemt af, hvor nødvendig denne eller hin produktionsgrens arbejdsprodukter er for en række andre enkeltkapitaler som disses materielle produktionsbetingelser. Fordelingen af kapitalen på de enkelte produktionsgrene er derimod bestemt af, hvor profitabelt produktionen er. Er profitraten undergennemsnitlig for en given produktionsgren vil tilstrømning af kapital ikke finde sted og anlæg af tillægskapital vil ophøre.

Det betyder, at de materielle produktionsbetingelser, som produceres af de pågældende produktionsgrene ikke længere produceres eller ikke længere produceres i tilstrækkeligt omfang, og derfor kan give anledning til statslig drift og/eller anlæg, afhængig af, hvor betydningsfuldt de pågældende arbejdsprodukter er i både stoflig og akkumulationsmæssig forstand for den samlede produktion eller dele af den. Det samme argument gælder for arbejdsprodukter, som udvikles som nye objektive betingelser for produktionen (jernbanetransportanlæg f.eks.) og som endnu ikke fremstilles kapitalistisk; statslige initiativer kan her overhovedet være en betingelse for etableringen af en produktion af de pågældende arbejdsprodukter.

Et eksempel kan belyse problemstillingerne omkring forholdet mellem de materielle produktionsbetingelser og den gennemsnitlige profitabilitet.

\section{TABEL 1. Indtægt (udbytte, henlæggelser, m.v.) i procent af aktiekapital for en række produktionsgrene i perioden 1917-24}

\begin{tabular}{lcrrrrrrr}
\hline & 1917 & 1918 & 1919 & 1920 & 1921 & 1922 & 1923 & 1924 \\
\hline Dampskibsselskaber & 63,3 & 81,7 & 108,4 & 45,8 & 11,5 & 14,2 & 11,5 & 5,7 \\
Sejlskibsselskaber & - & 11,2 & 19,9 & 12,3 & 1,1 & 1,1 & 2,0 & 1,5 \\
Jernbaneselskaber & 2,3 & 1,9 & 3,0 & 3,0 & 1,7 & 2,9 & 2,7 & 2,2 \\
Telefonselskaber & 17,1 & 21,5 & 38,2 & 28,9 & 17,3 & 17,9 & 22,4 & 21,1 \\
Industriselskaber & 30,9 & 24,2 & 23,8 & 15,7 & 7,6 & 10,1 & 14,2 & 13,8 \\
Elektricitetsselskaber & - & - & - & - & - & 14,8 & 15,9 & 16,1 \\
\hline
\end{tabular}

Kilde: Arbejderkommissionen af 1925, Bind II, København 1927, s. 260-263 og s. 314-315. (For elektricitetsselskaberne mangler oplysninger i perioden 1917-1921). 
Procenterne i tabel 1 kan med en vis forsigtighed tages som udtryk for profitrateniveauet i de forskellige produktionsgrene (ganske vist ses overskuddet ikke i forhold til anlægskapitalen, men i forhold til aktiekapitalen, men man kan med en vis rimelighed gå ud fra, at forskellen mellem anlægskapitalen og aktiekapitalen ikke varierer afgørende indenfor de forskellige produktionsområder).

Tabel 1 viser i såfald følgende: 1920'ernes krisegennemslag får virkning for alle produktionsgrene fra 1921 gennem faldende overskudsprocenter (faldende profitrater, svarende til totalprofitratens fald, forårsaget af krisen). Det vigtigste i denne sammenhæng er imidlertid, at der både før og efter krisegennemslaget er afgørende forskelle i profitrateniveauet mellem de forskellige produktionsgrene. Over hele perioden skiller jernbaneselskaberne sig ud med et meget lavt profitrateniveau. Efter krisegennemslaget får de følge af sejlskibsselskaberne.

Kapitalen vil som følge af det lave profitrateniveau tendentielt bevæge sig væk fra de to produktionsområder, som får følger for dels produktionens fremtidige omfang og for dels den fremtidige akkumulation og dermed udviklingen i produktionsområdernes profitproduktionsmetoder.

Hvorfor bliver jernbaneselskaberne i perioden så genstand for stigende statsliggørelse (statslig anlæg og drift, og statslige tilskud til privatbanernes anlæg og drift), når sejlskibsselskaberne ikke bliver det?

Der er en meget afgørende forskel mellem jernbaneselskaber og sejlskibsselskaber, nemlig i de årsager, som har ført til det lave profitrateniveau. For sejlskibsselskaberne er årsagen, at der er tale om et tilbagestående produktionsområde, som er under udkonkurrering fra dampskibsselskaberne, der repræsenterer en teknologisk set mere udviklet produktion af materielt set samme arbejdsprodukt henholdsvis produktionsbetingelse.

For jernbaneselskaberne er årsagen til det lave profitrateniveau, at den nødvendige anlægskapital er for stor i forhold til den andel af totalprofitmassen, som den kan opsuge. Det er især en følge af jernbanekapitalens lange omslagstid, men også en følge af anlægskapitalens minimumsomfang. Som følge af det lave profitrateniveau anlægges der kun i begrænset omfang tillægskapital i denne produktionsgren, som er med til at accellere en stadig faldende profitrate. ${ }^{27}$

En indskrænkning eller forsvinden af sejlskibstransportarbejdet er uden betydning for de berørte kapitalers særlige materielle produktionsbetingelser, fordi det erstattes af dampskibstransportarbejdet. Det samme gælder ikke for

27. Som eksempel kan nævnes, at privatbanerne i begyndelsen af 1930'erne får omfattende statsstøtte til et såkaldt moderniseringsprogram. Moderniseringsprogrammet koster ialt 12,5 mill. kr.; heraf betaler stat og kommune tilsammen 10,7 mill. kr., som klart viser, at privatbanerne ikke er en kapitalistisk tiltrækkende anlægssfære. Jvf. Betænkning II fra Moderniseringsudvalget; København 1933, bilag 10. 
jernbanetransportarbejdet, i det mindste ikke på dette tidspunkt. ${ }^{28}$ Det gør hele forskellen i spørgsmålet om statsliggørelsen i tilvejebringelsen af de pågældende særlige materielle produktionsbetingelser. ${ }^{29}$

Den danske produktions materielle produktionsbetingelser tilvejebringes ikke alene af den danske, men også af den udenlandske produktion. Gennem udviklingen af verdensmarkedet etableres de historiske forudsætninger for, at andre nationale kapitaler i stigende grad tilvejebringer dele af de nødvendige materielle produktionsbetingelser.

Det omstændighed, at en given produktionsgren ikke længere kan producere den tilstrækkelige profit, fører således ikke nødvendigvis til en statsliggørelse af den pågældende produktion. Det vil afhænge af, om de samme materielle produktionsbetingelser kan importeres. Eksistensen af højt udviklede kapitaler i andre lande og importen kan endog være årsagen til, at bestemte produktioner ophører her i landet. Et eksempel: i begyndelsen af 1930'erne ophørte avispapirproduktionen her i landet. Den danske papirkapital kunne ikke længere konkurrere (til trods for en beskyttelsestold); det var i hovedsagen en følge af en teknologisk udvikling i avispapirproduktionen, som forudsatte så store produktioner og så store anlægskapitaler, at den danske avispapirproduktion ikke kunne følge med. Ophøret af avispapirproduktionen betød imidlertid ikke en statsliggørelse af avispapirproduktionen, netop fordi den kapitalistiske fremstilling af avispapir uden

28. I 1926 undersøger en kommission, om automobildrift ville være mere rentabelt end jernbanedrift, og når frem til, at jernbanetransporten vil koste 6 øre pr. personkm og 25 $\emptyset$ re på tonkm, medens en automobilrute vil koste $9 \emptyset$ re pr. personkm og $66 \varnothing$ re pr. tonkm; i beregningerne indgår også anlæg af henholdsvis jernbane og vej. Jvf. Betænkning afgiven af den af ministeren for offentlige arbejder den 12. maj 1923 nedsatte kommission til undersøgelse af spørgsmålet om, hvorvidt alle de ved jernbanelovene af 1908 og 1918 vedtagne privatbaneanlæg $b \emptyset r$ fremmes samt om automobildrift med fordel kan foretrækkes for jernbanedrift m.v. København 1926, s. $56 f$.

29. Fester siger om de væsentlige årsager til statsliggørelsen, at der ingen grund er $» \ldots$ for en enkeltkapitalist tilat opretholde etkapitaludlægi etomfang, somikke afkasterden gennemsnitlige profit. Det eneste metodisk rigtige udgangspunkt må forudsætte dette.«; Fester, op.cit., s. 119-20. Samtidig forudsætter Fester, at en eventuel lav valoriseringsgrad (undergennemsnitlig merværdiproduktion) i princippet altid vil blive opvejet gennem dannelsen af produktionspriser, som sikrer en gennemsnitlig profitrate for den udlagte kapital. I overensstemmelse hermed bliver det afgørende for Fester eksistensen af en betalingsdygtigt efterspørgsel, idet en sådan efterspørgsel alene vil garantere dannelsen af produktionspriser og dermed etableringen af en gennemsnitsprofitrate indenfor området. Er efterspørgslen der ikke, vil nødvendigheden af en statslig fremstilling af det pågældende almene arbejdsmiddel være til stede. Heri ligger, at en for lille efterspørgsel fører til en for lav profitrate, fordi den for lille efterspørgsel hindrer etableringen af produktionsprisen (kostpris + gennemsnitsprofit). Det er imidlertid for isoleret blot at se på efterspørgslen, idet også en række andre forhold kan virke hindrende for produktionsprisens etablering. Samtidig overses udgangspunktet: anlægskapitalens relative størrelse i forhold til et givet marked, d.v.s. i forhold til Festers betalingsdygtige efterspørgsel. 
videre kunne lade sig gøre i en række andre kapitalistisk set mere udviklede lande.

Mulighed for import af bestemte arbejdsprodukter eller materielle produktionsbetingelser spiller således også en rolle for, hvorvidt et givet produktionsområde statsliggøres eller ej.

Set fra den nationale kapitals synspunkt kan det ovenstående sammenfattes således:

- tendensen til dannelse af gennemsnitsprofitraten fungerer ikke alene som en fordeler af den samfundsmæssige totalprofitmasse, men også som en fordeler af akkumulationen. Produktionsområder, som ikke kan udvise en relativt set tilstrækkelig profitabilitet, etableres ikke eller - hvis de er etableret - sygner hen uanset produktionsområdernes materielle betydning for den samlede produktion eller for dele af den.

- arbejdsprodukter fra ikke-etablerede eller hensygnende produktionsområder kan muligvis tilvejebringes over verdensmarkedet i den udstrækning de pågældende arbejdsprodukter produceres kapitalistisk i andre lande.

- arbejdsprodukter, som fungerer som materielle produktionsbetingelser, og som ikke produceres af den nationale kapital, eller kan tilvejebringes over verdensmarkedet, udgør potentielle statsliggørelsesfelter.

Som tidligere nævnt (jvf. fig. 1, s. 83) kan de materielle produktionsbetingelser for den umiddelbare produktionsproces opdeles i: arbejdsgenstande, arbejdsmidler i snæver forstand og arbejdsmidler i videre forstand. For en række arbejdsmidler i videre forstand, som kan karakteriseres som produktionsprocessens objektive betingelser, gælder det, at de i kraft af deres materielle karakter ikke kan indgå i den almindelige verdensmarkedshandel. Det er således ikke muligt at importere et samlet jernbaneanlæg (men nok visse dele af dens materielle bestanddele ${ }^{30}$ ), vejanlæg, oprensede vandløb, o.s.v.

I den udstrækning disse arbejdsmidler ikke kan fremstilles kapitalistisk bliver de umiddelbart genstand for statsligg ørelse, uafhængig af verdensmarkedet (og dermed også uafhængig af, om lignende arbejdsmidler fremstilles kapitalistisk eller ej i andre lande).

30. Som et kuriosum skal nævnes, at Ministeriet for offentlige arbejder i 1909 lod et udvalg unders $\emptyset \mathrm{ge}$ mulighederne for at skabe en lokomotivindustri her i landet, herunder om toldloven fra 1908 var en tilstrækkelig beskyttelse af en sådan industri. Jvf. Indberetning angaaende Lokomotivbygning i Danmark; København 1909. 
Arbejdsmidler i videre forstand indgår som en vigtig (og til tider eneste) bestanddel i det borgerlige infrastrukturbegreb. Det er en ufuldstændig forståelse af sammenhængen; det ses alene af det vilkårlige indhold begrebet har, når det skal konkretiseres. ${ }^{31}$

Statsliggjorte materielle produktionsbetingelser kan ikke reduceres til arbejdsmidler i videre forstand; disse produktionsbetingelser er oplagt mere omfattende; f.eks. elektricitetsproduktionen her i landet frem til 1950'erne og 1960'erne; elektricitet fungerer ikke som arbejdsmiddel i videre forstand, men derimod som arbejdsgenstand (hjælpestof).

Statsliggørelse af materielle produktionsbetingelsers fremstilling kan som tidligere nævnt - ikke reduceres til et stofligt spørgsmål. Det er ikke et givet produktionsområdes materielle karakter, som fører til statsliggørelsen, men derimod den manglende profitabilitet. Den manglende profitabilitet kan i visse tilfælde føres tilbage til produktionsområdets materielle karakter, men ikke altid..$^{32}$

\section{Undersøgelsesmetoder ved studie af særlige materielle produktionsbetingelsers statsliggørelse}

Det foregående har været et fors $\emptyset \mathrm{g}$ på at kritisere de unders $\emptyset$ gelsesmetoder, hvor der tages udgangspunkt i staten, og hvor hovedspørgsmålet er blevet, hvorvidt en given produktionsbetingelse er almen eller ej. Her overfor kan opstilles følgende metode eller undersøgelsesgang:

\section{Undersøgelse af givne materielle produktionsbetingelsers betydning for den kapitalistiske produktion. Det vil sige en undersøgelse af de kapitalistiske bestemmelser bag den produktive anvendelse af de mate- rielle produktionsbetingelser.}

31. Som eksempel herpå kan nævnes Budgetredegørelsen 1979; Finansministeriet, København 1979, afsnit 5, som taler om offentlig infrastruktur, og herunder forstår alt det, som koster statsapparatet penge, nemlig: trafik, kommunikation, miljø, bolig, energi, og som »er nødvendig for opretholdelsen af aktiviteten i samfundet iøvrigt« (s. 150).

32. Spørgsmålet om den manglende profitabilitet kan som hovedregel føres tilbage til omend det naturligvis ikke er identisk med, om arbejdet kan anvendes produktivt (jvf. det senere afsnit om statsliggørelse, s. 93-98). Produktivt arbejde er et spørgsmål om arbejdets subsumering under kapitalen. I den udstrækning produktet ikke kan adskilles fra den akt, som producerer det (gælder f.eks. transportarbejdet), danner produktionsområdets materielle karakter en hindring for subsumeringen, og den kapitalistiske produktionsmåde finder kun sted i indskrænket grad; jvf. Karl Marx: Resultater af den umiddelbare produktionsproces, Århus 1974, s. 120-121. 
Den problemstilling kan kun behandles historisk. Først når givne materielle produktionsbetingelser dukker op som en systematisk skranke for bestemte produktionsområders profitproduktion, er det muligt at spørge efter den kapitalistiske bestemmelse bag den produktive anvendelse af de materielle produktionsbetingelser, som er til undersøgelse. Den fortløbende kapitalistiske udvikling må også inddrages, især hvis denne udvikling afaktualiserer betydningen af de pågældende produktionsbetingelser. Endvidere kan problemstillingen ikke behandles generelt for hvilken som helst materiel produktionsbetingelse, fordi der vil være afgørende forskelle mellem de forskellige materielle produktionsbetingelser.

Eksempel: hvilken betydning har jernbanen (og for den sags skyld hele transportsystemet) for den kapitalistiske produktion. Det kunne eksempelvis generelt besvares således: akkumulationens uens fordeling på brancher og regioner fører til en stigende nødvendighed af transportarbejdet for at binde de arbejdsdelte produktioner sammen. Denne generelle besvarelse giver imidlertid ikke tilstrækkelige eksakte bestemmelser, som gør det muligt at forstå jernbanedriftens opståen og udvikling som materiel produktionsbetingelse. Der må anlægges en mere historisk betragtning.

Produktionsstrukturen før og omkring århundredskiftet er afgørende for jernbanetransportstrukturens etablering, ligesom den senere udvikling af produktionsstrukturen spiller en afgørende rolle for ændringer i jernbanetransporten. Især to produktionsområders struktur spiller en afgørende men forskellig rolle for jernbanenettets opbygning, nemlig landbrug og industri.

Landbrugets råstofforsyning (især mergel; kunstgødning, m.v.) og produkter (kreaturer, svin, korn og sukkerroer) stiller især krav til den lokale transportstruktur; lokalbanen bliver en vigtig materiel produktionsbetingelse for landbruget. ${ }^{33}$

Den del af industrien, som forarbejder landbrugsprodukter, har ved råstofforsyningen lokalbanen fælles med landbruget som materiel produktionsbetingelse. Den $\emptyset$ vrige del af industrien er ved råstofforsyningen i stigende grad afhængig af enten jernbaneforbindelser til havnebyer eller af forbindelser til det europæiske jernbanenet; det samme gælder for transporten af industriprodukter. Det betyder, at for industrien er det mindre lokalbanen og mere de

33. Lokalbanen som materiel produktionsbetingelse for landbruget fører endog til etablering af særlige baner, som udelukkende transporterer bestemte produkter: sukkerroerbaner og mergelbaner (iøvrigt også tørvebaner); jvf. Mergelbanekommissionens betænkning, Kbh. 1917, hvor oprettelse af mergelbaner med statstilskud og som sidebaner til statsbanerne foreslås. Resultatet bliver dog statstilskud til mergeltransporten på privat- og statsbanerne. 
længere, gennemgående banestrækninger, som bliver en afgørende materiel produktionsbetingelse.

Dette eksempel viser, at det ikke er tilstrækkeligt at konstatere transportarbejdets almindelige betydning for den fremvoksende kapitalisme. Ved fastlæggelsen af jernbanetransportarbejdets kapitalistiske bestemmelse er det nødvendigt at gå nærmere ind på spørgsmål som: hvordan ser produktionsstrukturen ud (bl.a. den samfundsmæssige arbejdsdeling, produktionens samfundsmæssiggørelse), hvordan afspejles produktionsstrukturen i det nødvendige transportsystem, hvilke forbindelser findes der mellem de forskellige produktionsområder (i og med, at landbrugsprodukter bliver til en materiel produktionsbetingelse (råstof) for industrien, bliver transporten også en materiel produktionsbetingelse for industrien i denne henseende), o.s.v.

Eksemplet dækker kun problemstilingen vedrørende jernbanedriftens etablering. Jernbanedriftens kapitalistiske nødvendighed og betemmelse vil naturligvis ændre sig med den kapitalistiske udvikling og bestemmelserne må derfor gøres til genstand for en historisk undersøgelse. Endvidere har eksemplets konkrete problemstillinger (produktionsstruktur og forbindelse mellem produktionsgrene) ikke gyldighed for en hvilken som helst materiel produktionsbetingelse. Ved en undersøgelse af de kapitalistiske bestemmelser bag andre materielle produktionsbetingelser må man stille andre spørgsmål.

Tidligere (jvf. side $76 \mathrm{f}$ ) er der argumenteret for, at det statsteoretiske undersøgelsesprogram, som Altvaters, Läpples og Festers løsningsfors $\emptyset$ g repræsenterer, presser produktionsbestemmelserne ud af analysen, enten ved overhovedet ikke at inddrage produktion i bestemmelsen af produktionsbetingelsernes begreb eller ved kun at inddrage den kapitalistiske produktionsproces i den udstrækning, den kan levere forklaringer på statsliggørelsen.

Det her anførte $f \emptyset r s t e$ unders $\emptyset$ gelsesfelt: en given materiel produktionsbetingelses betydning for den kapitalistiske produktion har til formål at løse dette problem; analysen må begynde med produktion og produktionsbetingelser og deres udviklingsbestemmelser; først når den er gennemført kan analysen af en eventuel statslig fremstilling af visse produktionsbetingelser påbegyndes.

Analysekravet om en historisk formidlet bestemmelse af en given materiel produktionsbetingelses betydning for den samlede kapitalistiske produktion eller for dele af den foruddiskonterer ikke statsliggørelsen, men giver svar på, hvordan givne arbejdsprodukter indgår som betingelse for produktionen.

Unders $\varnothing$ gelser indenfor dette felt må principielt adskilles skarpt fra det næste unders $\emptyset$ gelsesfelt: de pågældende arbejdsprodukter/produktionsbetingelsers fremstilling: 


\section{Undersøgelse af fremstillingen af givne materielle produktionsbetingelser; d.v.s. en undersøgelse af om de fremstilles kapitalistisk eller ej.}

De almene betingelser for kapitalistisk fremstilling af de arbejdsprodukter, som indgår i de materielle produktionsbetingelser, er tidligere behandlet, og kan sammenfattes således: det er et spørgsmål om en relativt set tilstrækkelig profitabilitet, d.v.s. et spørgsmål om et givet produktionsområdes profitrateniveau i forhold til den samfundsmæssige gennemsnitsprofitrate. Det er det samme som at sige, at de indkøbte produktionsmidler skal fungere som kapital og den indkøbte arbejdskraft skal være merværdiskabende.

Kan givne materielle produktionsbetingelser ikke fremstilles kapitalistisk og kan de ikke tilvejebringes over verdensmarkedet, så er det pågældende produktionsområde et potentielt statsliggørelsesfelt for den nationale kapital.

Det centrale problem er, hvad der overhovedet skal forstås med begrebet statsliggørelse. Der er her en række forskellige problemstillinger, som ikke kan behandles udtømmende i denne artikel, men nogle hovedlinier skal dog trækkes op.

Umiddelbart kunne man hævde, at hvis stat, amt, kommune (d.v.s. statsapparatet) tilvejebringer bestemte materielle produktionsbetingelser, så kunne man tale om statsliggørelse af de pågældende produktionsbetingelsers fremstilling. Det må være klart, at det ingen forskel gør, om det er staten, amterne eller kommunerne; det er imidlertid langt fra en tilstrækkeligt præcis bestemmelse af, hvad der skal forstås med statsliggørelse. Negativt kan statsliggørelsen afgrænses således:

- statsliggørelse betyder ikke, at staten (statsapparatet) gennem tilskud til de respektive enkeltkapitaler sikrer produktionen og dermed den fortsatte kapitalistiske fremstilling af de pågældende arbejdsprodukter/materielle produktionsbetingelser. Ganske vist står staten som garant for produktionen; uden statsstøtte ville den måske ophøre; men produktionen er stadig kapitalistisk, staten bryder blot ind eller kompenserer for virkningerne af de mekanismer, som fordeler den forhåndenværende profitmasse på de forskellige produktioner.

- statsliggørelse kan heller ikke blot bestå i, at staten overtager de produktioner, som ikke er tilstrækkeligt profitable, og driver disse produktioner videre som undergennemsnitlige kapitalistiske produktioner. Det kan selvfølgelig ikke udelukkes, og der findes eksempler på, at staten overtager en produktion eller som aktionær skyder en kapital ind i en produktion for at sikre dens fortsatte drift; men mellem denne form og den ovennævnte statsstøtte er der kun gradsforskelle. Begge former for statslige initiativer berører ikke den pågældende produktions kapitalistiske karakter, og kan ikke karakteriseres som statsliggørelse. 
Med statsliggørelse må derimod forstås en ikke-kapitalistisk eller ikkeproduktiv produktion. Spørgsmålet om produktiv henholdsvis uproduktivt arbejde rejser en række spørgsmål, hvor her kun skal behandles nogle få.

Om et arbejde er produktivt eller ej har intet at gøre med arbejdets indhold. »Produktivt arbejde er kun et forkortende udtryk for hele forholdet og måden, hvorpå arbejdsevnen og arbejdet figurerer i den kapitalistiske produktionsproces. (...) Produktivt arbejde bytter sig direkte mod penge som kapital, dvs. med penge, som ifølge sin bestemmelse er kapital, har bestemmelsen at fungere som kapital og træder overfor arbejdsevnen som kapital. Produktivt arbejder er altså sådan, som for arbejderen kun reproducerer hans arbejdsevnes tidligere bestemte værdi, hvorimod det som værdiskabende virksomhed $\emptyset$ ger kapitalens værdi, og sætter de værdier, det har skabt overfor arbejderen som kapital. Det specifikke forhold mellem det genstandsgjorte og det levende arbejde, gør det første til kapital, og gør det sidste til produktivt arbejde. « ${ }^{34}$

I forhold til statsliggørelsen er det afgørende her, at de statslige midler, som anvendes til fremstilling af de materielle produktionsbetingelser, $i k k e$ anlægges som kapital og ikke fungerer som kapital, d.v.s. som en selvforøgende værdi.

Det statslige udlæg har sin oprindelse i skatten, og ikke fra en forudgående kapitalistisk produktion; det statslige udlæg er således ikke led i en kapitalakkumulation. $^{35}$

Med udlægget køber staten de forskellige bestanddele, som medgår til fremstillingen af f.eks. jernbanen og til fremstilling af transportarbejdet. Statens køb består af skinner, sveller, rullende materiel, arbejdskraft, m.v. Arbejdskraften betales efter sin værdi i samme udstrækning eller i lighed med arbejdskraften i den umiddelbare produktionsproces; det betyder også, at det statslige uproduktive arbejde også potentielt indeholder en ubetalt del. Den statslige uproduktive arbejder yder på samme måde ubetalt arbejde, men det ubetalte arbejde går tabt for staten d.v.s. merarbejdet realiseres ikke. Det statslige uproduktive arbejde $\emptyset$ ger ikke de udlagte statsmidlers værdi. For arbejdsproduktet dannes der ikke en markedsværdi; de statslige midler fordeles ikke udlægsmæssigt på de enkelte produktionsområder efter den størst mulige profit, o.s.v. Kort og godt: de kapitalistiske cirkulationsbetingelser gælder heller ikke for den statsliggjorte produktion.

34. Karl Marx: Resultater af den umiddelbare produktionsproces, Århus 1974, s. 116 (uden originaltekstens fremhævelser).

35. Skattepengene er ikke et ækvivalentbytte; staten sælger ikke varer for at få skattepenge, men eksproprierer en del af totalprofitmassen; jvf. iøvrigt Tyge Kjar: Introduktion til problemstillingen: statsapparatets $\varnothing$ konomiske grundlag; i: TEK/SAM-grundkursus, 1979/80, bd. I, s. 95-103. 
Sammenfattende: statsliggørelsen af fremstillingen af givne materielle produktionsbetingelser betyder også, at arbejdet ikke fungerer produktivt og at de udlagte midler ikke fungerer som kapital.

\subsection{Cirkulationsform for de statsliggjorte materielle produktionsbetingelser}

Den kapitalistiske produktion har formen: P-V-P', hvor pengene fungerer som kapital, d.v.s. fungerer som en selvforøgende værdi. Heroverfor står formen: $\mathrm{V}-\mathrm{P}-\mathrm{V}$, hvor pengene kun fungerer som cirkulationsmiddel (det er eksempelvis den form som er karakteristisk for handelskapitalens cirkulationsform). Det er også denne form, som er grundformen for statsmidlernes anvendelse ved fremstillingen af de materielle produktionsbetingelser, dog med følgende modifikationer: P, som for staten er skattepenge, stammer ikke fra et varesalg eller ækvivalentbytte, men derimod fra beskatningen, som er at forstå som en ekspropriation. Det vil sige, at for staten gælder formen: ekspropriation - skattefond - varek $\varnothing \mathrm{b}$, som omend kun i formel forstand modsvarer formen V-P-V. ${ }^{36}$ Varek $\varnothing$ bet er k $\varnothing \mathrm{b}$ af de produktionsmidler og arbejdskraft, hvormed statsapparatet tilvejebringer de pågældende materielle produktionsbetingelser.

36. Det uproduktive arbejde konsumeres for dets brugsværdis skyld, og konsumeres ikke som bytteværdisættende arbejde, derfor formen V-P-V; som tidligere nævnt er transaktionen V-P for statens vedkommende ikke et ækvivalentbytte, men ekspropriation; transaktionen P-V er statslig $\mathrm{k} \emptyset \mathrm{b}$ af de bestanddele, hvormed de statsliggjorte materielle produktionsbetingelser fremstilles.

»Hans arbejde bliver da konsumeret for sin brugsvardis skyld, og ikke som byttevardisattende, det bliver konsumeret uproduktivt og ikke produktivt. Kapitalisten står derfor ikke overfor ham [den uproduktive arbejder] som kapitalist, som repræsentant for kapitalen. Han bytter [derimod] sine penge mod arbejdet som revenu og ikke som kapital. Arbejdets konsumtion konstituerer ikke P-V-P', men V-P-V (den sidste er selve arbejdet eller tjenesten). Pengene fungerer her kun som cirkulationsmiddel, ikke som kapital «. Karl Marx: Resultater, op.cit., s. 114. Det afgørende er, at det arbejde, som konsumeres for dets brugsværdi, ikke samtidig er bytteværdisættende. Det gør ingen forskel, om det er kapitalisten eller staten, som konsumerer dette arbejde; i begge tilfælde byttes pengene mod arbejdet som revenu og ikke som kapital. Hertil kan føjes følgende bemærkning fra Marx: »Kapitalens højeste udvikling findes, når de almene betingelser for den samfundsmæssige produktionsproces ikke fremstilles af et fradrag fra det samfundsmassige revenu, at statsskatterne - hvor revenu, ikke kapital, optrader som

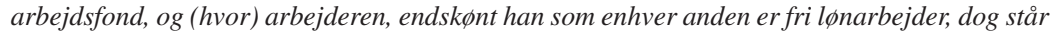
$i$ et andet фkonomisk forhold - men af kapitalen som kapital.«; (min fremhævelse) - fra Karl Marx: Grundrids, Århus/København 1975, bd. 2, s. 400.

I den udstrækning kapitalens højeste udvikling ikke forefindes, står den pågældende lønarbejder i et andet $\emptyset$ konomisk forhold, nemlig et uproduktivt forhold; arbejdet er ikke (bytte) værdisættende, og er baseret på det statslige revenu. 
For det meste er benyttelsen eller anvendelsen af statsligt tilvejebragte materielle produktionsbetingelser gjort betinget af en afgifts- eller takstbetaling, som umiddelbart fremtræder som en betaling for benyttelsen af de pågældende materielle produktionsbetingelser.

Forekomsten af afgiftsbetalingen giver let det indtryk, at den statslige tilvejebringelse af materielle produktionsbetingelser alligevel følger formen: P-V-P', altså den kapitalistiske form i modificeret udgave, nemlig efter formen: skattepenge - statslig vareproduktion - afgifter. Men det er ingenlunde tilfældet; det ses alene af den meget forskelligartede politik, der gælder for betalingen af benyttelsesafgifter eller takster.

For visse områder er afgifterne afpasset den pris, som gælder for tilsvarende arbejdsprodukter, som er fremstillet ad kapitalistisk vej. For andre områder satses der på afgiftsbetaling, som får området til at »hvile i sig selv«; og igen andre områder har en minimal afgiftsbetaling. ${ }^{37}$

Det afgørende er imidlertid, at afgifterne på ingen måde opvejer de skattepenge, som indgår; der er ikke tale om et ækvivalentbytte, idet afgifterne/ taksterne ikke udtrykker den samfundsmæssige arbejdstid, som medgår til fremstillingen af de materielle produktionsbetingelser. De udlagte skattepenge fungerer heller ikke som selvforøgende værdi, har ikke deres oprindelse i akkumulationen, men derimod i ekspropriationen.

Afgiftsbetalingen kan således ikke opfattes som betaling for anvendelse/benyttelse af de pågældende materielle produktionsbetingelser, men må ses som en skatteform uden direkte forbindelse med de produktionsmidler og det arbejde, som er anvendt ved fremstillingen af produktionsbetingelserne i statsligt regi.

Med statsbanerne som eksempel skal det kort vises, at det ved den statslige tilvejebringelse af materielle produktionsbetingelser ikke er tale om kapitalistisk produktion, belyst ved forholdet mellem udlæggets størrelse og takstbetalingens størrelse (jvf. tabel 2).

37. For statsbanernes vedkommende er taksterne delvis fastsat efter EF-forordninger: således har EF's ministerråd vedtaget regler for harmonisering af visse bestemmelser, der har indvirkning på konkurrencen inden for transporterhvervene; driftstilskuddet til DSB (de 823 mill. kr. i tabel 2, side 100) er ligeledes reguleret efter EF-forordninger (de såkaldte kompensationsordninger). Princippet om, at området skal »hvile i sig selv« er et princip, der fastsætter, at indtægterne, dvs. takster og afgifter skal modsvare udgifternes størrelse. Det betyder ikke kapitalistisk produktion, men derimod følgende: den statsrevenu, de skattepenge, som anvendes til fremstillingen af de pågældende materielle produktionsbetingelser, skal modsvares af en tilsvarende statsrevenu, skattepenge. Hvile-i-sig-selv-princippet fraviges hyppigt. Eksempelvis for Kommunekemis vedkommende er »afgifterne gennemsnitlig (...) fastsat 20-30\% lavere, end de skulle være, såfremt anlægget skulle hvile i sig selv«; jvf. Miljøreformen. En foreløbig redegørelse om miljøreformens virkninger; Kbh. 1979, s. 78. Netop fordi takster og afgifter ikke er betaling for det tilsatte arbejde, altså ikke er udtryk for et ækvivalentbytte, kan afgifter og takster hæves eller sænkes efter bestemte fortsæt; afgiftspolitiken er ikke bundet til de bestemmelser, som gælder for markedsværdien og den med den forbundne konkurrence »Det bør (...) overvejes (...) at anvende vandafgifter (og evt. vandafledningsafgifter) som middel til at opnå besparelser i vandforbruget og i spildevandsbortskaffelse«, Miljøreformen, 1979, op.cit., s. 218. 
TABEL 2. Statsbanernes driftsresultater i finansåret 1975-76, samt opgørelse over driftsresultater, hvis et tilsvarende produktionsanlæg blev drevet (kunne drives) som kapitalistisk produktion. I mill. kr.

\begin{tabular}{lcc}
\hline & $\begin{array}{c}\text { DSB drevet som } \\
\text { statsligt anlæg: }\end{array}$ & $\begin{array}{c}\text { Tilsvarende anlæg } \\
\text { kapitalistisk drevet: }\end{array}$ \\
\hline Driftsudgifter: & 2.689 & 2.689 \\
- løn: & 1.581 & 1.581 \\
- materialeudgifter mv: & 1.108 & 1.108 \\
Driftsindtægter: & 1.866 & 3.983 \\
Statstilskud til drift: & 823 & - \\
Profitfond: & - & 1.294 \\
Anlæg (som statstilskud): & 753 & - \\
Anlæg (som akkumulation): & - & 753 \\
Overskydende profitmasse: & - & 541 \\
\hline
\end{tabular}

Kilde: Efter det normaliserede regnskab, i: Forslag til Finanslov for Finansåret 1977-78. Driftsindtægter for et tilsvarende kapitalistisk drevet anlæg er beregnet på basis af en forudsætning om, at driftsindtægterne skulle sikre en profitkvote (1-w), svarende til gennemsnittet for hele industrien i årene 1975-76. Egne beregninger.

Tabellen viser, at det samlede statstilskud til statsbanerne er på knap 1,6 mia. kr. Dette statstilskud er større end den profitmasse, som en i omfang modsvarende kapitalistisk produktion ville kunne producere under gennemsnitlige betingelser.

Selvom afgifterne eller taksterne blev sat op, så de indbragte knap 4,0 mia. kr. (det ville i sagens natur være en usandsynlig forudsætning), og DSB dermed ville have et overskud, som svarede til det, der gælder for almindelig kapitalistisk produktion, så ville DSB ikke dermed automatisk blive en kapitalisisk produktion. Det er tidligere argumenteret herfor, men det skal gentages her: statsliggørelsen består både i, at arbejdsdagens ubetalte del går tabt for staten, d.v.s. at arbejdet ikke fungerer produktivt, men også at de anlagte midler ikke fungerer som kapital, både som en merværdiproducerende og som en akkumulerende størrelse.

Og omvendt: hvis taksterne uden videre kunne sættes op, d.v.s. kunne sættes op uden væsentlige indskrænkninger i f.eks. godstransporten, så de ialt indbragte de 4,0 mia. kr., ville det betyde, at betingelserne nu var til stede for en kapitalistisk produktion indenfor dette produktionsområde. 
Sammenfattende: afgift- eller takstbetalingen er ikke et ækvivalentbytte; lige værdier byttes ikke. Derimod er afgift- eller takstbetalingen en skatteform blandt mange andre. De statsliggjorte materielle produktionsbetingelser fremstilles indenfor formen: ekspropriation - skattefond - varer, og er ikke blot kapitalistiske produktioner med permanent underskud, dækket ind ved statstilskud.

\subsection{Statsliggørelsen og den kapitalistiske udviklingsgrad}

De sammenhænge, som er påpeget $\mathrm{i}$ det foregående, har nogle vigtige konsekvenser for forståelsen af statens rolle. I og med at den statslige fremstilling af materielle produktionsbetingelser har sit udspring formelt set $\mathrm{i}$ formen V-P-V, forudsætter statsliggørelsen overhovedet, at statsapparatet har mulighed for ekspropriation af profitmasse i en vis størrelsesorden. Den forudsætter altså, at statsapparatet kan beslaglægge en del af det samfundsmæssige merarbejde, som igen forudsætter en vis udviklingsgrad i den kapitalistiske produktion og de til den hørende cirkulationsformer.

Statsliggørelsen af tilvejebringelsen af materielle produktionsbetingelser i den form, der her er tale om, finder derfor ikke sted forud for den kapitalistiske produktions opståen, men efter. På denne måde forudsætter statsliggørelsen af visse produktionsområder eksistensen af kapitalisme; den er ikke en moderne form for merkantilisme.

Statsliggørelsen er ikke en produktionsmåde adskilt fra den kapitalistiske produktion, men en del af den, fremkommet ved de historiske betingelser, som gælder for den kapitalistiske produktion overhovedet, og som særlige produktionsområder ikke kan opfylde (jvf. den tidligere diskussion om den tilstrækkelige profitabilitet).

Statsliggørelsen i den form, som der her er redegjort for, er hverken »blandings $\varnothing$ konomi «, nationalisering, plan $\varnothing$ konomi eller statskapitalisme; det er slet og ret uproduktiv produktion.

Sagen kan også betragtes fra den totale produktions synsvinkel: gennem statsliggørelsen af dele af produktionen behersker kapitalen ikke direkte hele produktionen. Den omstændighed, at en del af den samlede produktion drives uproduktivt, betyder, at den samlede profitmasse potentielt formindskes, svarende til den profitmasse, som går tabt ved den statsliggjorte produktion, som altså går tabt ved, at en del af den samfundsmæssige arbejdstid ikke forvandles til merarbejdstid gennem forvandling til profit. 
På den ene side berøver den statslige fremstilling af de materielle produktionsbetingelser totalkapitalen for en given mængde profit ved at berøve den et antal produktive arbejdere. På den anden side frembringes de materielle produktionsbetingelser billigere for de enkeltkapitaler, som gør brug af dem, end hvis betingelserne skulle fremstilles kapitalistisk. Totalkapitalen lider tab, enkeltkapitalerne beriges. ${ }^{38}$

Dette forhold er delvis reflekteret i den betydning, der i den borgerlige opfattelse tillægges staten i forhold til, hvad der kaldes de infrastrukturelle anlæg. Den gennemgående opfattelse er, at staten gennem de infrastrukturelle anlæg universielt skaber betingelser for industriel vækst (d.v.s. enkeltkapitalistisk berigelse), men samtidig må omfanget af statsligt producerede materielle produktionsbetingelser begrænses af hensyn til omfanget af de midler, som statsapparatet beslaglægger, og af hensyn til omfanget af det merarbejde, som statsliggørelsen bringer ud af cirkulation. ${ }^{39}$

Statsliggørelsen af fremstillingen af de materielle produktionsbetingelser er ikke et udtryk for den højeste udvikling af kapitalismen. Statsliggørelsen kan efter de bestemmelser, som er udviklet i det foregående - derimod opfattes som »hjælpeforanstaltninger « i de tilfælde, hvor kapitalen overhovedet ikke, ikke længere eller endnu ikke behersker det pågældende produktionsområde. Marx udtrykker det således: $:^{40} \gg$ Kapitalens højeste udvikling findes, når de almene betingelser for den samfundsmæssige produktionsproces ikke fremstilles af et fradrag fra det samfundsmæssige revenu, [ikke fremstilles] af statsskatterne $-[\ldots]-$ men af kapitalen som kapital «.

Herfra kan man ikke slutte, at jo mere kapitalismen udvikler sig, jo mere vil statsliggørelsen aftage, fordi »kapitalens højeste udvikling«ikke er en direkte

38. Det gør sig gældende, selvom afgifter og takster følger et princip om, at fremstillingen skal hvile i sig selv. Det vil være endnu mere udpræget, hvis fremstillingen af de pågældende materielle produktionsbetingelser udviser et underskud; det betyder nemlig, at det statsrevenu, som anvendes til fremstillingen, ikke modsvares af en tilsvarende skatteopkrævning i form af takster og afgifter.

39. I egnsudviklingsdiskussionerne er manglen på infrastrukturelle anlæg blevet gjort til årsag til den manglende økonomiske vækst i udkantsområderne; i de seneste egnsudviklingsdiskussioner kommer modsætningen frem mellem på den ene side statslig fremstilling af de materielle produktionsbetingelser som lokale vækstbetingelser, og så på den anden side den begrænsning, det medfører i totalprofitmassen, dels gennem statslig beslaglæggelse af profit som statsrevenu og dels gennem den uproduktive anvendelse af arbejdskraft. Industrirådet afviser således etableringen af lokale vækstcentre (såkaldte egnscentre), men ønsker de materielle produktionsbetingelser udbygget omkring de store industrielle basisbyer. »Det moderne velstands- og velfærdssamfund er afhængigt af industriens produktion. Men industrien er tilsvarende afhængig af store offentlige investeringer i veje, værker, kloakering og rensning m.v. Ifald disse investeringer skal sikres en rimelig økonomisk udnyttelse - målt i antallet af virksomheder og beskæftigede - må man undgå en uforholdsmassig fysisk spredning af disse kostbare anlag «. (Min fremhævelse). Fra: Industrien og den fysiske planlægning; Industrirådet, København 1978, s. 27.

40. Karl Marx: Grundrids, op.cit., s. 400. 
følge af kapitalismens almindelige udvikling. Men man kan heller ikke slutte sig til det modsatte (som f.eks. Läpple gør), nemlig at statsliggjort fremstilling af de materielle produktionsbetingelser får et stadigt stigende omfang.

Statsliggørelsen af materielle produktionsbetingelser vil i det historiske udviklingsforl $\varnothing \mathrm{b}$ hele tiden være modstillet reprivatiseringstendenser, d.v.s. tendenser til (fornyet) etablering af kapitalistisk produktion indenfor de pågældende produktionsområder. Det kan alene en oversigt over de produktionsområder, der fra tid til anden har været eller fortsat er statsliggjorte, anskueliggøre.

Her må dog indskydes følgende bemærkning: der er tidligere redegjort for, at arbejdskraften ikke kan betragtes som en materiel produktionsbetingelse; arbejdskraften er ganske vist en materiel kraft, men hverken den eller arbejderen indgår på samme måde i produktionsprocessen som arbejdsgenstande og arbejdsmidler. Arbejdskraften og arbejderen kan opfattes som en del af de almene produktionsbetingelser, hvorunder de materielle produktionsbetingelser er et særligt område. På samme måde indgår f.eks. sygehusvæsnet (sundhedsvæsnet) ikke i de materielle produktionsbetingelser, men nok i de almene produktionsbetingelser i den udstrækning sygehusene sikrer eller genopretter arbejderklassens helbred. Persontransporten opfattes heller ikke som en materiel produktionsbetingelse - af samme grund som ovenfor.

Selvom f.eks. sygehuse, persontransport, o.s.v. ikke kan opfattes som materielle produktionsbetingelser, består der dog en parallel problemstilling vedrørende deres arbejdsprodukter: de kan drives produktivt eller uproduktivt, d.v.s. kapitalistisk eller statsliggjort. Men eksempelvis vil betingelserne for en kapitalistisk fremstilling være vidt forskellig fra det, som gælder fremstillingen af de materielle produktionsbetingelser, især i kraft af disse arbejdsprodukters anden stilling i den samlede produktions- og reproduktionsproces.

Følgende produktionsområder har været fremstillet eller fremstilles statsligt, amtsligt eller kommunalt, d.v.s. uproduktivt. Det må påny understreges, at ikke nødvendigvis hele produktionsområdet drejer sig om en fremstilling af materielle produktionsbetingelser; hovedparten af produktionsområderne omfatter også en samtidig fremstilling af arbejdsprodukter, der konsumeres individuelt og derfor er underlagt et helt andet bestemmelsesforhold end de materielle produktionsbetingelser: ${ }^{41}$

41. Den individuelle konsumtion af f.eks. transportarbejde kan have en sådan betydning og et sådant omfang, at denne konsumtion kan overskygge den betydning, som transportarbejdet har som materiel produktionsbetingelse. Denne side er overhovedet ikke inddraget i denne sammenhæng; her drejer det sig kun om at behandle fremstillingen af de materielle produktionsbetingelser; denne fremstilling kan naturligvis også være pæget af den individuelle konsumtion af de samme arbejdsprodukter (eller tilnærmelsesvis samme arbejdsprodukter). 
- post- og telegrafvæsen (en betænkning i 1880'erne fastslog at telegrafvæsnet efter sin natur ikke var egnet til spekulation, d.v.s kapitalistisk produktion, og derfor skulle drives statsligt).

- jernbaneanlæg og jernbanetransport (de private jernbaner har samlet stort set været under afvikling siden deres opblomstringsperiode i begyndelsen af århundredet).

- vejanlæg (her i landet findes ikke eksempler på kapitalistisk drevne vejanlæg).

- havneanlæg og havnedrift (historisk en blanding af statslige, kommunale og private havne).

- lufthavneanlæg og lufthavnedrift (blanding af statslig og privat anlæg og drift).

- vandforsyning (også en blanding).

- vandafledning/kloakering (kommunalt og amtsligt).

- elektricitetsproduktion og -forsyning (fra primært kommunalt til privat anlæg og drift).

- telefonvæsen (primært privat anlagt og drevet).

- rensningsanlæg, m.v. (blanding).

- etablering af industriarealer (byggemodning - mere og mere kommunalt).

- gasværker og naturgasanlæg (primært kommunalt/amtsligt).

Herudover findes der en række enkeltstående områder, som for længere eller kortere tid har været drevet af forskellige dele af statsapparatet (f.eks. driver Sønderjyllands Amt en asfaltfabrik). o.v.s.

Det er karakteristisk, at fremstillingen af arbejdsprodukter indenfor de nævnte områder samtidig har været eller fortsat er drevet både kapitalistisk (hyppigt med statstilskud) og statsliggjort. Det viser, at det for den historiske udvikling ikke er muligt at opstille en entydig udviklingsretning gående enten mod stigende statsliggørelse eller stigende produktion på grundlag af kapital som kapital (reprivatisering). Det er imidlertid karakteristisk, at forskydninger i en hidtidig udviklingstendens hyppigt ændres som følge af de længerevarende kriseperioder.

For nogle områder har der dog fundet en mere entydig reprivatisering sted. Nogle eksempler skal nævnes.

Jernbanedriften udviser et kompliceret billede, fordi der er tale om udviklingstræk i begge retninger. Anlægningen af privatbanerne kulminerede i perioden 1890-1920. Siden da er statsbanerne især gennem privatbanernes nedlæggelse blevet alt dominerende, hvad angår jernbanetransporten af gods; men ser vi på den samlede godstransports fordeling er udviklingen en anden. 
I 1950 fandt 34\% af transporten (i ton-km) sted på jernbaner; i 1975 var det kun 7\%, medens vare- og lastbiltransporten var steget fra $49 \%$ af godstransporten til 79\%; resten var skibsfarttransport. ${ }^{42}$ Vare- og lastbiltransporten drives kapitalistisk, enten som en særlig produktionsgren eller som inkorporeret $\mathrm{i}$ anden kapitalistisk virksomhed, men har dog sin produktionsmæssige forudsætninger i vejbygningen, som fremstilles statsliggjort (statsligt, amtsligt eller kommunalt).

På denne baggrund kan man hævde en stigende statsliggørelse i jernbanegodstransporten, men en reprivatisering af godstransporten som sådan.

Elektricitetsværker, som tidligere udpræget har været drevet kommunalt (og statsligt), og telefonvæsnet, som har haft en mindre statslig del i Vestjylland, er eksempler på produktionsområder, som nu fuldstændigt er reprivatiseret. ${ }^{43}$

\section{Afsluttende bemærkninger}

Sammenfattende om de unders $\emptyset$ gelsesmetoder, som der er fors $\emptyset$ gt argumenteret for i denne artikel, kan der siges følgende: i undersøgelsen af de materielle produktionsbetingelser og deres fremstilling må man først undersøge betydningen af givne arbejdsprodukter for den kapitalistiske produktion, d.v.s. undersøge de kapitalistiske bestemmelser bag givne arbejdsprodukters nødvendighed som materielle produktionsbetingelser for hele eller dele af den umiddelbare produktionsproces.

Dette unders $\emptyset$ gelsesfelt er nødvendigt, hvis begrebet for de materielle produktionsbetingelser skal knyttes til den umiddelbare produktionsproces, og ikke begrebsmæssigt knyttes til de omstændigheder, der kun gælder de færreste af de materielle produktionsbetingelsers fremstilling, nemlig statsliggørelsen.

42. Oplysninger fra: Godstransportarbejdets udvikling i perioden 1950-73; t-ATV rapport 8. juli 1975. Trafik 2000, udgivet af ATV's Trafikforskningsgruppe; her citeret efter: Industrien og den fysiske planlægning; Industrirådet, København 1978, s. 38.

43. Reprivatiseringen kan antage en række forskellige former. Staten kan købe de materielle produktionsbetingelser i større eller mindre grad som færdigprodukt, halvfabrikata, o.s.v. Frem for eksempelvis selv at bygge et rensningsanlæg, kan statsapparatet bestille det hos en entreprenør; anlægsarbejdet udføres i såfald produktivt. Jvf. diskussionen heraf hos Sybille von Flatow \& Freerk Huisken: Den borgerlige stats afledningsproblem, II, Kurasje nr. 10, s. $49-52$. 
Dernæst kan statsliggørelsen behandles, eller rettere først da kan begreber for de materielle produktionsbetingelsers eventuelle uproduktive fremstilling behandles; til statsliggørelsen hører modbegrebet: reprivatisering.

Den fremlagte undersøgelsesgang er til syvende og sidst et spørgsmål om abstraktionsprocedure; for at kunne behandle de materielle produktionsbetingelser må der i første omgang abstraheres fra deres fremstilling, uanset om det sker på basis af kapital eller et statsfond. Gennemføres den omvendte abstraktion, som det er tilfældet ved det tidligere kritiserede statsteoretiske unders $\emptyset$ gelsesprogram, bliver de materielle produktionsbetingelser identisk med de materielle produktionsbetingelser, som fremstilles af statsapparatet. 